\title{
Behavioural, Haematological and Histopathological Changes in the African Catfish, Clarias gariepinus Exposed to 2,4- Dichlorophenoxyacetic Acid (2,4-D)
}

\author{
Okogwu, O. I., Anionwo, Q., Anoke D. C., Ugwuezi, P. 0. \\ Applied Biology Department, Ebonyi State University, Abakaliki, Ebonyi State, Nigeria
}

(Received 30:10:2015; Accepted 06:12:2015)

\begin{abstract}
The herbicide, 2,4-D is commonly used to control broad leaf weeds in agriculture and to eliminate aquatic weeds. Run-offs to floodplains that serve as breeding sites of some fish species such as Clarias gariepinus is common. This study was undertaken to evaluate the effects of 2,4-D on the behaviour, haematology and histology of the African catfish, C. gariepinus, in order to understand its toxicity. Juvenile catfish weighing $10.03 \pm 14.1 \mathrm{~g}$ were exposed to lethal concentrations and subsequently three sublethal concentrations $(0.43,0.58$ and $0.72 \mathrm{mg} / \mathrm{L})$ of 2,4-D. The behaviour of the fish was observed during exposure and after $96 \mathrm{~h}$, the blood and tissues from the liver, kidney, fin, brain and gills were collected and analyzed. The result showed that exposed fish displayed signs of asphyxiation. The packed cell volume (PCV), red blood cell (RBC) and haemoglobin (Hb) significantly decreased by $17-40 \%$ while white blood cell (WBC) increased significantly $(p<0.05)$ by $78-137 \%$ in a concentration dependent pattern. Histopathological analysis showed extensive damage to the liver, kidney, fin, brain and gills of the fish exposed to sublethal concentration, which suggests that 2,4-D causes deleterious harm to hepatocytes and renal, neural, fin and gill cells. Damage to the gill filaments could impair oxygen uptake resulting in asphyxia and consequently death over a period. The study clearly shows that $C$. gariepinus is highly susceptible to the toxicity of 2,4-D, therefore the use of this herbicide in rice paddies near the breeding sites of the fish should be discouraged.
\end{abstract}

Keywords: Clarias gariepinus, 2,4-D, herbicide, histopathology, haematology

Correspondence: okeyokogwu@gmail.com

\section{Introduction}

The world is presently faced with the challenge of feeding the ever growing human population. The high demand for food has necessitated extensive use of agrochemicals (fertilizers, herbicides and pesticides) to boost food production, in order to meet demand. These chemicals, when applied, boost agricultural productivity through improved soil fertility and elimination of weeds and pests. 2,4-Dichlorophenoxyacetic acid (2,4-D; CAS no 94-75-7) is one of the chemicals used to control weeds (Van Ravezwaay et al., 2003; Barbieri 2008; Browne and Moore, 2014). It belongs to the family of herbicides collectively known as phenoxy compounds, which are extensively used to control broad leaves weeds (Bukowska, 2006). It is a selective plant killer that disrupts numerous enzymatic activities in plant, inhibit photosynthesis, plug phloem, alter cell division and obstruct water and salt transportation in plants (Barbieri, 2008).

Unfortunately, due to extensive use and/or misapplication, 2,4-D can diffuse into the aquatic ecosystem through surface runoffs. On reaching water bodies, this toxicant is easily absorbed by organisms through consumption, respiration and skin (Browne and Moore, 2014). Studies have shown that organisms exposed to 2,4-D exhibit deleterious behavioural, physiological, immunological, histological, neurological and 
haematological changes (Tuschl and Schwab, 2003; Stürtz et al., 2008; Uyanikgil et al., 2009; Kubrak et al., 2013). The toxicological pathway of 2,4-D has been linked to over production of reactive oxygen species (ROS), leading to oxidative stress, cell damage and apoptosis (Atamaniuk et al., 2013; Kubrak et al., 2013; Matviishyn et al., 2014).

USEPA (2005) stated that the maximum predicted concentration of 2,4-D in aquatic habitat is between 2000 and $4000 \mu \mathrm{g} / \mathrm{L}$, while the reported maximum concentration in freshwater aquatic ecosystem range from 0.015 to $75 \mu \mathrm{g} / \mathrm{L}$ (Coady et al., 2013). The estimated half life in the aquatic environment is between 2.5 and 3.2 days (Wilson and Arbruster, 2007) as it is easily degraded in the environment by microorganisms. However, consistent and sustained application of this chemical, especially in rice paddies could increase the environmental concentration above levels previously recorded.

The herbicide, 2,4-D, is widely applied in Nigeria to control weeds in rice paddies. Rice farming in southern Nigeria is predominantly carried out in river basins due to the high water demand of rice and limited upland irrigation capacities of most farmers. This implies that agrochemical run-offs to surrounding waters near these farmed areas are, as would be expected, high. Coincidentally, these river basins, especially the vegetated banks proximally close to the rice paddies are the foraging and breeding homes of some economically important fish species such as Clarias gariepinus (Okogwu and Ugwumba 2012). These fish species are therefore potentially exposed to sublethal concentrations of 2,4-D, frequently and are thus most likely to suffer some adverse sublethal effects. This study was undertaken to evaluate the behavioural, haematological and histopathological response of $C$. gariepinus to sublethal concentrations of 2,4-D as may be found in the environment. This is necessary to establish its toxicity, which will be useful in the advocacy of policy change.

\section{Materials and methods}

Experimental Fish Specimens and Chemicals: Juveniles of $C$. gariepinus weighing $10.03 \pm 4.1 \mathrm{~g}$ and with a mean length of $10.83 \pm 1.5 \mathrm{~cm}$ were obtained from the Department of Fisheries and Aquaculture,
Ebonyi State University, Nigeria. They were acclimated for two weeks in the Department of Applied Biology Laboratory, Ebonyi State University, Nigeria prior to the experiment. During acclimation, the fish were fed commercial catfish food at $2 \%$ of their body weight daily. Thereafter, the fish were exposed to varying concentrations of 2,4-D: 0.0 (control), 0.72, 0.86, 1.08, 1.22 and $1.44 \mathrm{mg} / \mathrm{l}$ in ten liters of water per concentration for 96 hours to determine the concentration that kills $50 \%$ of the fish $\left(\mathrm{LC}_{50}\right)$. Afterward, the fish were randomly divided into four groups ( $A, B, C$ and $D)$ of ten fish each and exposed to sublethal concentrations of the toxicant. The groups were administered 0.0 (control), $0.43,0.58$ and $0.72 \mathrm{mg} / \mathrm{L}$ of $2,4-\mathrm{D}$, respectively. Group A served as the control and all experiments were carried out in triplicates. During the experiment, the behaviour of the fish and other external changes in the body of the fish were observed. At the end of the 96h experiment, two fish from each tank (six fish per group) were removed, the blood collected and then euthanized. The liver, kidney, brain, gill and fin were subsequently removed and preserved with normal saline for histological analysis.

Haematological Analysis: 5-10mL of blood sample was collected from the posterior caudal vein with a $20 \mathrm{~mL}$ disposable heparinised syringe. To estimate red blood cell, the whole blood was first diluted using Daices fluid in a ratio of 1:50 (blood: Diaices fluid. The diluted blood was then introduced onto the edge of the cover slip and counted using a haemocytometer with the aid of compound microscope. Therefore:

No of Red Blood Cells per $\mathrm{mm}^{3}=$ number of cells counted in $0.02 \mathrm{~mm}^{3} \times 50$ (area counted) x 50 (dilution)

To estimate the white blood cell, $1 \mathrm{ml}$ of whole blood was diluted using the Turk's solution and then counted in counting chamber. The number of cells occurring per $\mathrm{mm}^{3}=$ number of cells counted in $0.02 \mathrm{~mm}^{3} \mathrm{x}$ 10 (area counted) x 50 (dilution). The packed cell volume (PCV) was obtained by centrifuging $1 \mathrm{ml}$ of whole blood in capillary tube using microhaematocrit centrifuge at $4000 \mathrm{rpm}$ for 10 minutes. The spun tube was placed in a scale and the PCV read as percentage of the whole blood. The PCV was calculated as PVC $=$ No of cell counted $\times 10 \times$ $25 \times 10 \times 20\left(10^{4} \mathrm{~mm}^{3}\right)$. Haemoglobin was 
estimated using Haemoglobinometer based on acid haematin method (Zander et al. 1984):

Haemoglobin $=\frac{\text { value obtained } \times 17,2 \mathrm{mg} / 100 \mathrm{ml}}{100}$

Histopathological Analysis: The organs (liver, kidney, brain, gill and fin) were fixed in $10 \%$ normal saline, dehydrated using different grades of alcohol ranging from $70 \%, 90 \%$ to absolute alcohol for ten minutes each. They were then dried by immersion in three (3) changes of xylene for ten (10) minutes each. This was followed by impregnation in paraffin wax in a hot oven at a temperature of $60^{\circ} \mathrm{C}$. Blocks were made and sectioned at $5 \mu \mathrm{m}$ thickness using a rotary microtome. Sections were rehydrated in distilled water and stained with Hematoxylin-Eosin $(\mathrm{H}-\mathrm{E})$, then examined and micrographed under light microscopy (Tayeb et al. 2010).
Statistical Analysis: The dose response of mortality were analyzed by probit analysis based on computer programme. This was used to derive the $\mathrm{LC}_{50}$, median lethal concentration that causes $50 \%$ mortality of exposed animals. The statistical difference between test groups was estimated with Analysis of variance (ANOVA) using Statistical Programme for Social Sciences (SPSS) software, version 15 .

\section{Results}

Physicochemical variables: The temperature of the test water varied from $28.8^{\circ} \mathrm{C}$ to $29.4^{\circ} \mathrm{C}$ and the $\mathrm{pH}$ varied between 7.4 and 7.9. The conductivity of the water varied between 688 and $802 \mu \mathrm{S} / \mathrm{cm}$, while the TDS varied from 390 to $489 \mathrm{mg} / \mathrm{L}$, and both increased with increase in the concentration of the toxicant. Unlike conductivity and TDS, dissolved oxygen content decreased with increased concentration of 2, 4-D as shown in Table 1.

Table 1. Physicochemical parameters recorded before the commencement of the toxicity test.

\begin{tabular}{lcccc}
\hline Concentration of $2,4-\mathrm{D}(\mathrm{mg} / \mathrm{L})$ & $\mathrm{A}$ (control) & $\mathrm{B}$ & $\mathrm{C}$ & $\mathrm{D}$ \\
& 0 & 0.43 & 0.58 & 0.72 \\
\hline Temperature $\left({ }^{\circ} \mathrm{C}\right)$ & $28.8 \pm 0.5$ & $29.4 \pm 0.8$ & $29.7 \pm 0.5$ & $29.0 \pm 1.0$ \\
$\mathrm{pH}$ & $7.7 \pm 0.1$ & $7.6 \pm 0.2$ & $7.5 \pm 0.3$ & $7.4 \pm 0.3$ \\
Conductivity $(\mu \mathrm{S} / \mathrm{cm})$ & $688 \pm 5$ & $802 \pm 12$ & $811 \pm 10$ & $845 \pm 12$ \\
Dissolved Oxygen $(\mathrm{mg} / \mathrm{L})$ & $6.8 \pm 0.2$ & $3.0 \pm 0.3$ & $2.5 \pm 0.5$ & $2.0 \pm 0.8$ \\
TDS $(\mathrm{mg} / \mathrm{L})$ & $390 \pm 11$ & $460 \pm 10$ & $467 \pm 10$ & $489 \pm 11$ \\
\hline
\end{tabular}

The $\mathrm{LC}_{50}$ of 2, 4-D for C. gariepinus was estimated as $1.12 \mathrm{mg} / \mathrm{L}$ using the probit analysis, as shown in Fig 1.

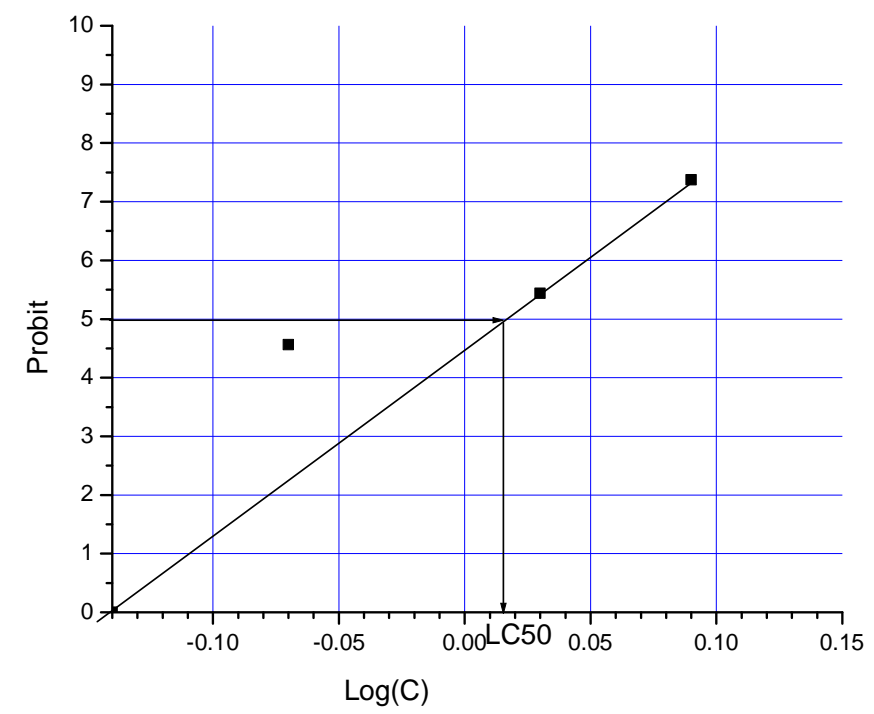

Figure 1: Probit method of estimating median lethal concentration ( $\left.L C_{50}\right)$ of 2,4-D in Clarias gariepinus

$$
\left(\mathrm{LC}_{50}=1.04 \mathrm{mg} / \mathrm{L}\right)
$$


Behavioural effects: During the sublethal test, the behaviour of the fish in the control tanks was normal, while fish in the tank containing varying concentrations of 2,4D showed different abnormal behaviours such as erratic swimming (movement), erect posture, respiratory stress, restlessness, incessant jumping, gasping for air and sudden quick movement. The fish exposed to $0.43 \mathrm{mg} / \mathrm{L}$ concentration of 2,4-D showed erratic swimming, gasping for air at 24 and 48 hours post exposure period. Those exposed to $0.58 \mathrm{mg} / \mathrm{L}$ concentration of 2,4-D showed erect posture at 24, 48, 72 and 96 hours and also somersaulting (incessant jumping) at 24, 48 and 72 hours. At higher concentration
$(0.72 \mathrm{mg} / \mathrm{L})$, the fish became very weak and settled to the bottom. At the end of the 96 hours bioassay, no mortality was observed.

Heamatological effects: Exposure of $C$. gariepinus to $0.43 \mathrm{mg} / \mathrm{L}$ of $2,4-\mathrm{D}$ caused $17.8 \%, 25 \%$ and $17.1 \%$ significant decrease in PVC, RBC and $\mathrm{Hb}$, respectively but $78 \%$ increase in WBC compared to the control. The PVC, RBC and $\mathrm{Hb}$ decreased significantly $(p<0.001)$ by $21.4 \%, 25 \%$ and $21.5 \%$ respectively while WBC increased by $102 \%$ in the $0.58 \mathrm{mg} / \mathrm{L}$ group. Exposure to $0.72 \mathrm{mg} / \mathrm{L}$ of $2,4-\mathrm{D}$ led to $39.2 \%, 37.5 \%$ and $38.7 \%$ significant decrease in PVC, RBC and $\mathrm{Hb}$ respectively and $137 \%$ significant increase in WBC compared to the control (Table 2).

Table 2. Changes in level of PVC, WBC, RBC and $\mathrm{Hb}$ of $\mathrm{C}$. gariepinus exposed to different concentrations 2,4-D for 96h

\begin{tabular}{lllll}
\hline Group/Concentration of & A (control) & B & C & D \\
2,4-D (mg/L) & 0 & 0.43 & 0.58 & 0.72 \\
\hline PCV & $28.0 \pm 0.2^{\mathrm{a}}$ & $23.0 \pm 4.0^{\mathrm{b}}$ & $22.0 \pm 20^{\mathrm{b}}$ & $17.0 \pm 3.0^{\mathrm{b}}$ \\
WBC & $12.0 \pm 0.1^{\mathrm{a}}$ & $21.4 \pm 0.2^{\mathrm{b}}$ & $26.1 \pm 0.3^{\mathrm{b}}$ & $28.4 \pm 0.3^{\mathrm{b}}$ \\
RBC & $3.2 \pm 00^{\mathrm{a}}$ & $2.4 \pm 0.2^{\mathrm{b}}$ & $2.4 \pm 0.2^{\mathrm{b}}$ & $2.0 \pm 0.3^{\mathrm{b}}$ \\
Hb & $9.3 \pm 00^{\mathrm{a}}$ & $7.7 \pm 0.3^{\mathrm{b}}$ & $7.3 \pm 0.2^{\mathrm{b}}$ & $5.7 \pm 0.2^{\mathrm{b}}$ \\
\hline
\end{tabular}

Note: figures along the row with the same superscripts are not significantly different $(\mathrm{P}<0.001)$

Histopathology: Histological examination of the liver in the control fish revealed the typical darkly stained specks of necrotic nuclei, and normal hepathocytes (Fig $2 a$ ), while in the $0.43 \mathrm{mg} / \mathrm{L}$ there was focal loss of hepatic tissue with clumping in some areas, giving rise to mild hepatic architectural distortion. In the $0.57 \mathrm{mg} / \mathrm{L}$ group, there was an infiltration of inflammatory cells, and also focal loss of hepatic tissue with a mild hepatic architectural distortion. Finally, in the $0.72 \mathrm{mg} / \mathrm{L}$ there were focal areas of aggregation of inflammatory cells with hepatic architectural distortion (Fig 2).

The histopathological observation of kidney cells from the control group C. gariepinus exposed to $0.00 \mathrm{mg} / \mathrm{L}$ of $2,4-\mathrm{D}$ showed normal glomeruli and tubular. But the group exposed to $0.43 \mathrm{mg} / \mathrm{L}$, showed intact renal architecture with the loss of glomeruli. At $0.56 \mathrm{mg} / \mathrm{L}$, there was mild distortion of renal architecture with minimal loss of glomeruli and congestion of vessels. The fish exposed to $0.72 \mathrm{mg} / \mathrm{L}$ of $2,4-$ $\mathrm{D}$ showed loss of tissue and fragmentation as well as intra-renal haemorrhage (Fig 3). The fin of the control group showed normal fin with finger-like projections, but, those exposed to different concentrations of 2,4-D showed degenerated fin in concentrationdependent manner. Observed abnormalities include distortion in normal arrangement of the fin, degeneration of the muscles, fragmentation of the muscle and also distortion in normal arrangement of the fin (Fig

4). 

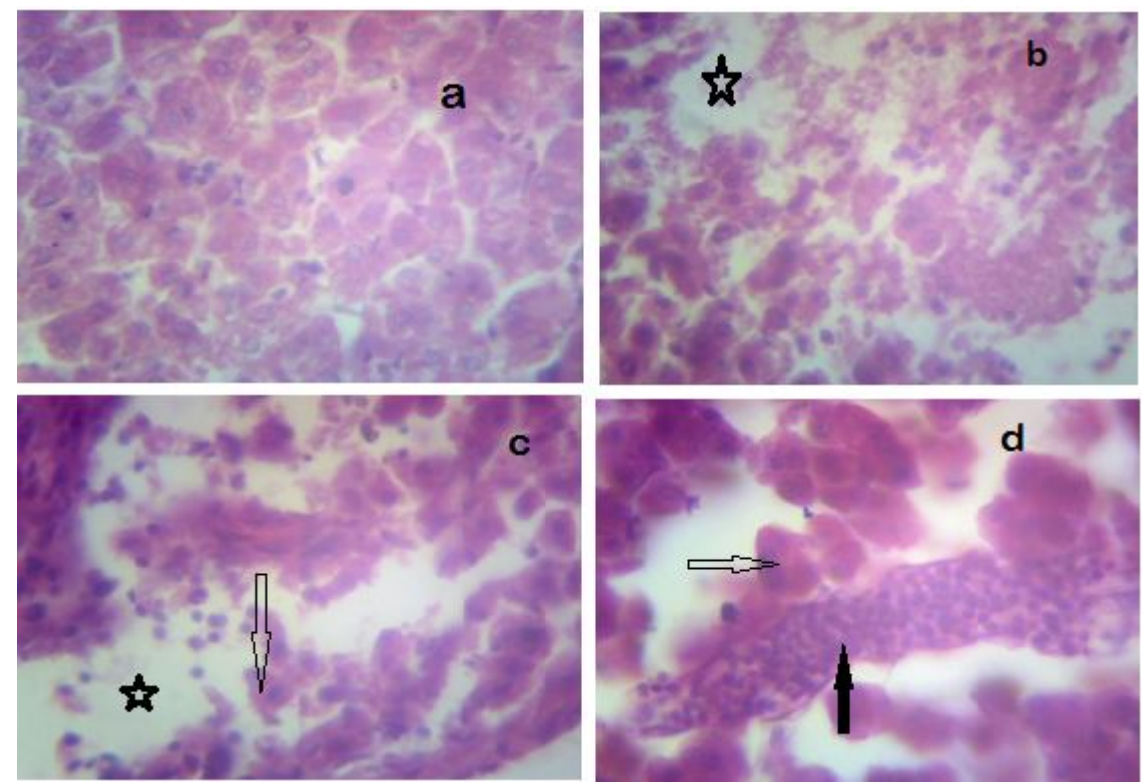

Figure 2. Histopathological changes in the liver of C. gariepinus exposed to $0.36 \mathrm{mg} / \mathrm{L}(\mathrm{b}), 0.57 \mathrm{mg} / \mathrm{L}$ (c) and $0.72 \mathrm{mg} / \mathrm{L}$ (d) of 2,4-D for $96 \mathrm{~h}$ compared to control (a). The star (b) shows focal loss of hepatic tissue, arrow pointing down (c) shows degenerated muscle fibers, right pointing arrow (d) shows dissociated hepatocytes and upward pointing black arrow (d) shows picnotic nuclei.
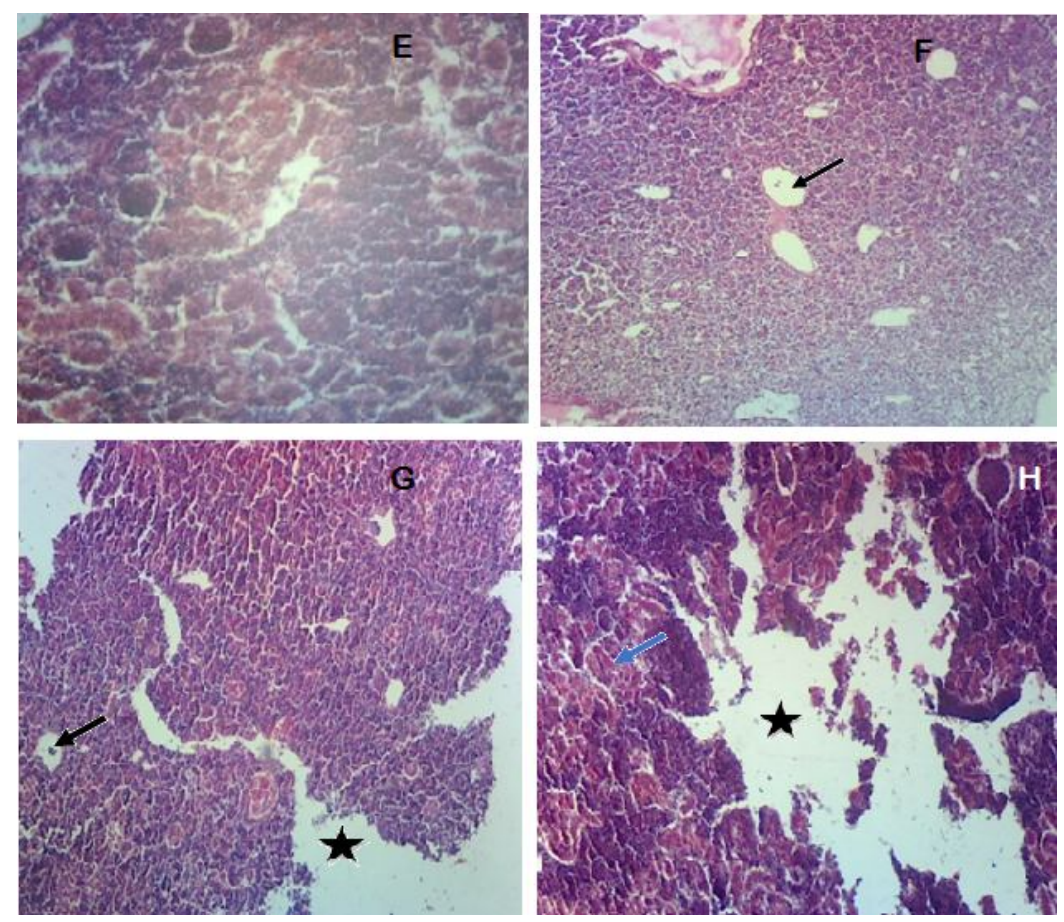

Figure 3. Histopathological changes in the kidney of $C$. gariepinus exposed to $0.36 \mathrm{mg} / \mathrm{L}(\mathrm{F})$, $0.57 \mathrm{mg} / \mathrm{L}(\mathrm{G})$ and $0.72 \mathrm{mg} / \mathrm{L}(\mathrm{H})$ of 2,4-D for $96 \mathrm{~h}$ compared to control $(\mathrm{E})$. The black arrow (F) shows loss of renal tissue, black star $(\mathrm{G})$ shows loss glomerulus, blue arrow $(\mathrm{H})$ fragmentation

There is no observable change in the heart of control fish, however in the group exposed to $0.43 \mathrm{mg} / \mathrm{L}$, there was mild loss of tissue with intra cardiac haemorrhage. In the $0.57 \mathrm{mg} / \mathrm{l}$ and $0.72 \mathrm{mg} / \mathrm{l}$ groups, there was intra-cardiac muscular haemorrhage, blood clot within the chamber and focal area of tissue loss (Fig 5).

Histopathological observation of the brain cells of fish exposed to 2,4-D showed that the control fish brain had normal granular 
and molecular layers. But in the $0.43 \mathrm{mg} / \mathrm{L}$ concentration group, mild spongiosis was observed, while the $0.56 \mathrm{mg} / \mathrm{L}$ and the $0.72 \mathrm{mg} / \mathrm{L}$ group showed moderate spongiosis, infiltration of inflammatory cells, and acute inflammation of neutrophils, respectively. (Fig 6).
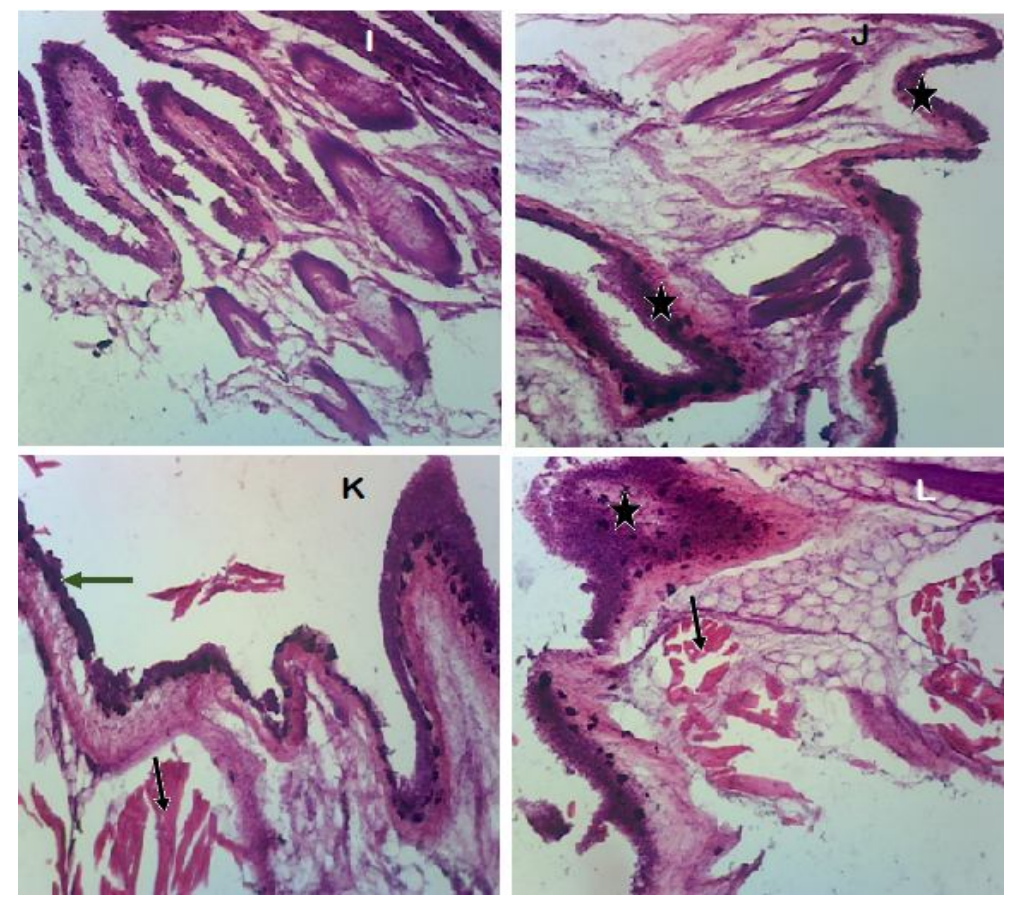

Figure 4: Histopathological changes in the fin of C. gariepinus exposed to $0.36 \mathrm{mg} / \mathrm{L}(\mathrm{J}), 0.57 \mathrm{mg} / \mathrm{L}$ $(\mathrm{K})$ and $0.72 \mathrm{mg} / \mathrm{L}$ (L) of 2,4-D for $96 \mathrm{~h}$ compared to control (I). The black star (J) shows picnotic nuclei, the green and black arrow (K) show distortion of fins (DF) and the degeneration of the muscle and black star $(\mathrm{L})$ show picnotic nuclei
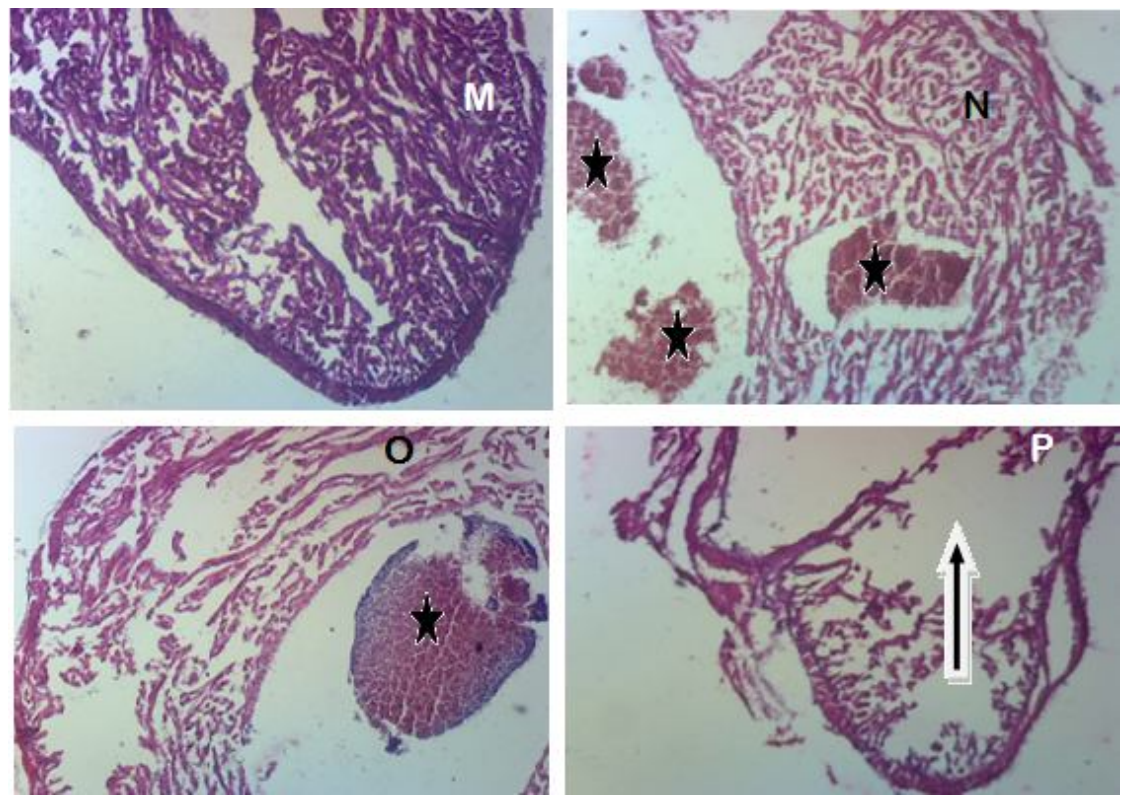

Figure 5. Histopathological changes in the heart of C. gariepinus exposed to $0.36 \mathrm{mg} / \mathrm{L}(\mathrm{N}), 0.57 \mathrm{mg} / \mathrm{L}$ (O) and $0.72 \mathrm{mg} / \mathrm{L}(\mathrm{P})$ of $2,4-\mathrm{D}$ for $96 \mathrm{~h}$ compared to control (M). The black star shows cardiac haemorrhage and the arrow show loss of tissues 

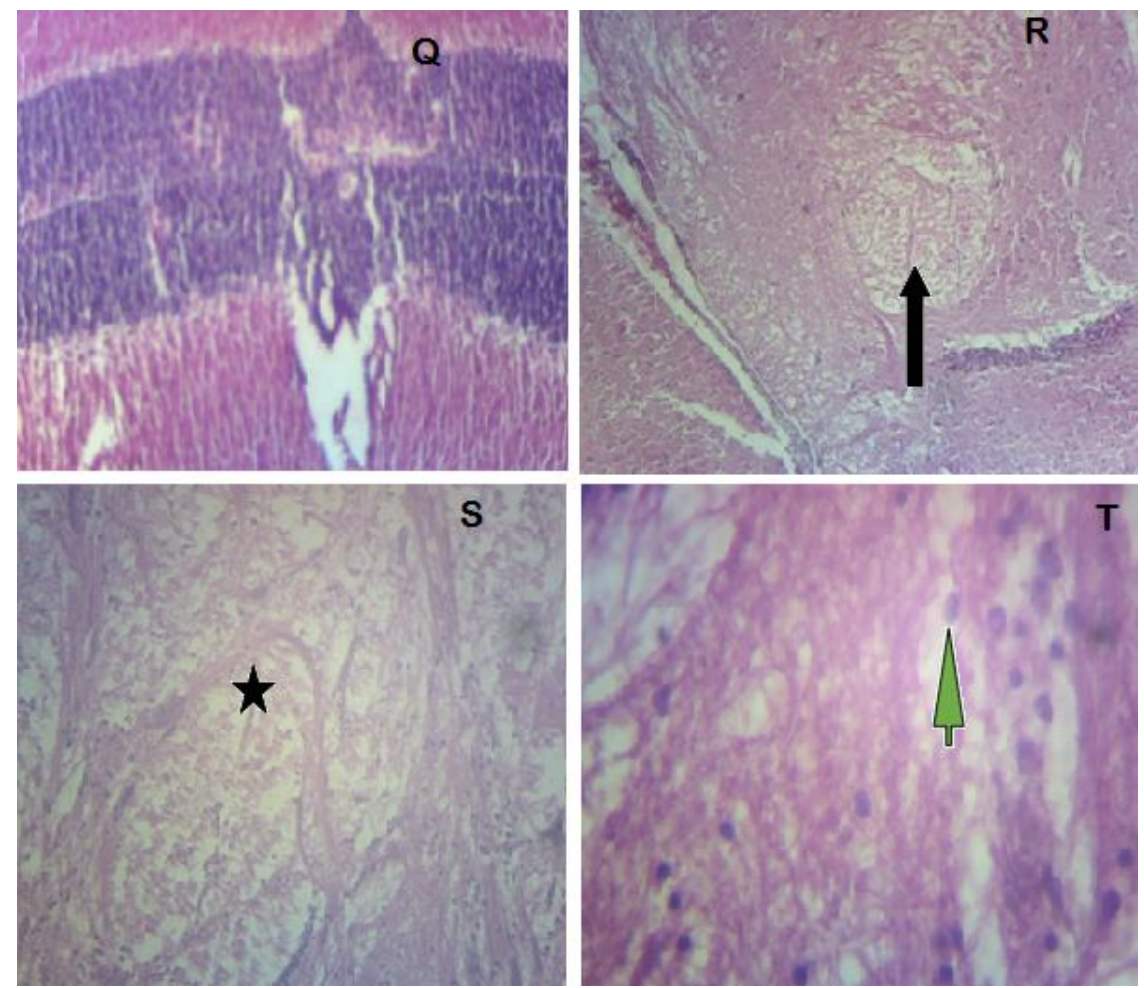

Figure 6. Histopathological changes in the brain of C. gariepinus exposed to $0.36 \mathrm{mg} / \mathrm{L}(\mathrm{R}), 0.57 \mathrm{mg} / \mathrm{L}(\mathrm{S})$ and $0.72 \mathrm{mg} / \mathrm{L}(\mathrm{T})$ of 2,4-D for $96 \mathrm{~h}$ compared to control (Q). The black arrow star shows mild spongiosis, the star shows moderate spongiosis and the arrow head shows infiltration of inflammatory cells.

The gills from the control fish showed normal primary lamellar filament and secondary lamellar. Histological examination of the gills of C. gariepinus exposed to 2, 4-D showed several pathological changes and their frequencies increased with increase in the concentration of the toxicant. At $0.43 \mathrm{mg} / \mathrm{L}$ there were epithelia lifting with loss of some

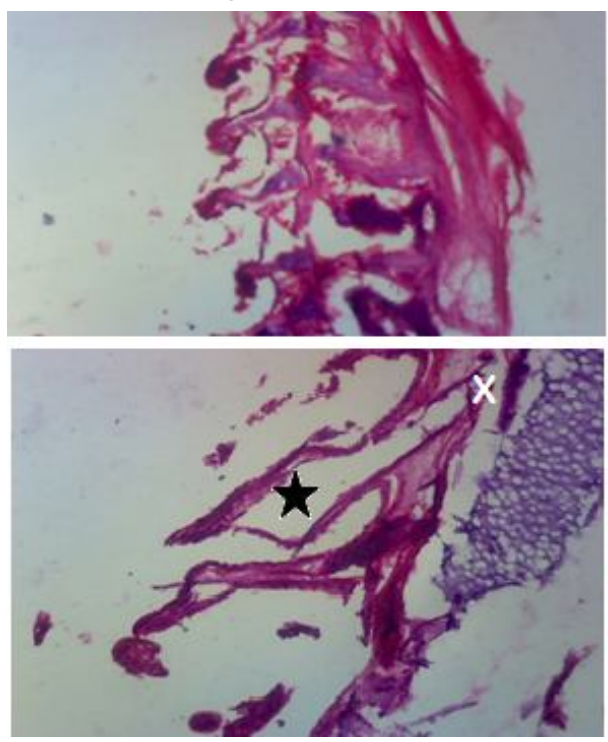

Figure 7: Histopathological changes in the gill of $C$. gariepinus exposed to $0.36 \mathrm{mg} / \mathrm{L}(\mathrm{U}), 0.57 \mathrm{mg} / \mathrm{L}(\mathrm{V})$ and $0.72 \mathrm{mg} / \mathrm{L}(\mathrm{X})$ of 2,4-D for $96 \mathrm{~h}$ compared to control $(\mathrm{Y})$. The black arrow star shows epithelia lifting; The green arrow in X shows fragmentation of the epithelium, stalk and base of the gill. parts of epithelium for gaseous exchange, while in the $0.57 \mathrm{mg} / \mathrm{L}$ and $0.72 \mathrm{mg} / \mathrm{L}$ group, there were thinning out of the projecting stalk of the epithelium with loss in some parts of the epithelium and fragmentation of the epithelium, the stalk and the base of the gill (Fig 7). The severity of anomaly was concentration-dependent.

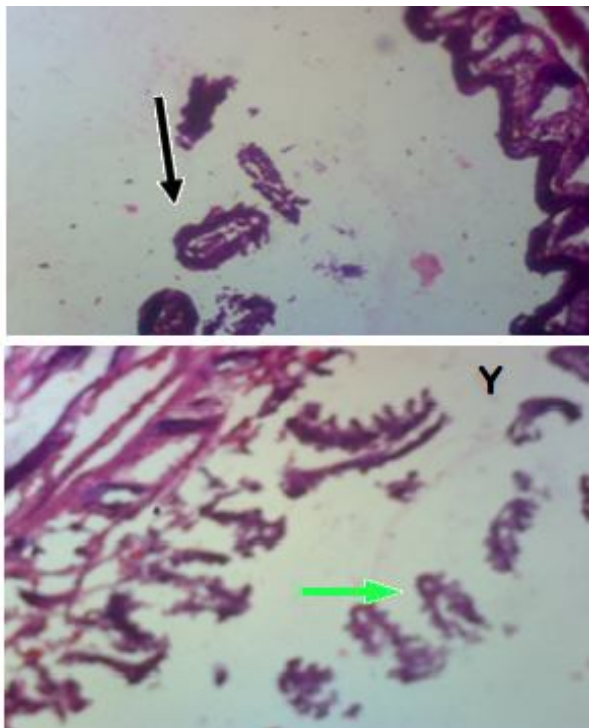




\section{Discussion}

The herbicide, 2,4-D has been well reported to induce behavioural and toxicological changes in fish but not Clarias gariepinus. Previous studies reported $96 \mathrm{~h} \mathrm{LC}_{50}$ of 5.1-35mg/L for Cyprinus carpio (Vardia and Durve, 1981), 15-45mg/L for Geophagus brasiliensis (Barbieri, 2008), 50-80mg/L for Clarias batrachus, Channa punctatus and Heteropneustes fossilis (Farah et al., 2004). These values are above the $96 \mathrm{~h} \mathrm{LC}_{50}$ of $1.12 \mathrm{mg} / \mathrm{L}$ observed in this study, which clearly shows that Clarias gariepinus is more susceptible to toxicity at a lower concentration of 2,4-D than most fish species are to this toxicant and as a consequence needs a well coordinated protective plan against it.

Observed behavioural changes, such as erratic swimming, gasping for air, sudden quick movement and somersaulting are similar to changes linked to the toxicity of xenobiotics on fish as have been reported in previous studies (Ferrando et al., 1991; Sarikaya and Yilmaz 2003). Perhaps, such behavioural changes could be attributed to both the direct toxicity of the chemical or the deterioration of water quality. For example at higher concentration of $2,4-D(>0.43 \mathrm{mg} / \mathrm{L})$, it was observed that most of the fish were projecting their heads out of water to gasp for fresh air indicating that they were apparently having dissolved oxygen problems. However, such behaviour could also be attributed to damage to the gills, which impairs oxygen uptake and leads to toxicity induced hypoxia. Our findings tend to support the observation of Barbieri (2008), who observed that exposure to 2,4-D led to lowered oxygen consumption in Geophagus brasiliensis.

The haematological results showed that PVC, RBC and $\mathrm{Hb}$ decreased significantly while the WBC increased significantly in the fish exposed to 2,4-D in a concentration related pattern. This however, differ from the observations of Velisek et al. (2006), who noted that Cypermethrin had no effect on the blood indices of Oncorhynchus mykiss. Haematological changes as recorded in this study are attributed to rapid destruction of the red blood cells by the toxicant and the increase in WBC was probably a defensive mechanism deployed by the fish to protect itself from the assault of 2,4-D.

The present study also showed that all the evaluated organs were damaged. The liver of C. gariepinus exposed to the different concentration of 2,4-D showed distortion of hepatic architecture and extensive damage to hepatocytes, which is consistent with previous reports on the toxicity of xenobiotics such as herbicides and pesticides (Tayeb et al., 2010), metals (Muhammad et al., 2011) and microcystins (Okogwu et al., 2014). The kidney and cardiac cells were also extensively damaged as renal and intra cardiac haemorrhages were observed, which depict loss of blood due to cellular damage and could lead to organ failure. The brain showed mild spongiosis and infiltration of inflammatory cells and neutrophils, which could lead to brain damage.

2,4-D caused loss of parts of the epithelium and fragmentation of the stalk and the base of the gill. These damages to the gill have wider implications and could lead to asphyxia and death of the fish over a period of time as recorded by some researchers (Misra et al., 1985, Barbieri et al., 2002, Barbieri 2008).

\section{Conclusion}

The $96 \mathrm{~h} \quad \mathrm{LC}_{50}$ of 2,4-D for C. gariepinus is very low and equivalent to concentrations that are found in the environment. The results of this study showed that 2,4-D reduced water quality and caused adverse behavioural changes in $\mathrm{C}$. gariepinus. The cells of different organs of exposed fish were also damaged, suggesting that this commonly used herbicide is extremely toxic to the fish and there is need for cautious application near the breeding sites of $\mathrm{C}$. gariepinus. There is also need for protective policy to ensure that the breeding sites (floodplains) are protected from agricultural runoffs through the establishment of buffer zones.

\section{Acknowledgement}

The authors are grateful to the Department of Applied Biology for the provision of facilities used for this study.

\section{References}

Atamaniuk, T.M., Kubrak, O.I., . Storey, K.B. And Lushchak, V.I. (2013). Oxidative stress as a mechanism for toxicity of 2,4dichlorophenoxyacetic acid (2,4-D): studies 
with goldfish gills. Ecotoxicology 22:14981508.

Barbieri, E., Serralheiro, P.C. And Rocha, I.O. (2002) The use of metabolism to evaluate the toxicity of dodecil benzen sodium sulfonate (LAS-C12) on the Mugil platanus (mullet) according to the temperature and salinity. J. Exp. Mar. Biol. Ecol. 277:109-127.

Barbieri, E. (2008). Effect of 2,4-D herbicide (2,4-dichlorophenoxyacetic acid) on oxygen consumption and ammonium excretion of juveniles of Geophagus brasiliensis (Quoy \& Gaimard, 1824) (Osteichthyes, Cichlidae). Ecotoxicology 18:55-60.

Browne, A.M. And Moore P.A. (2014). The Effects of sublethal levels of 2,4Dichlorophenoxyacetic Acid Herbicide (2,4-D) on feeding behaviours of the crayfish Oreochromis rusticus. Arch. Environ. Contam. Toxicol. 67:234-244

Bukowska, B. (2006). Toxicity of 2,4Dichlorophenoxyacetic Acid - Molecular Mechanisms. Polish J. of Environ. Stud. 15:365-374

Coady, K., Marino, T., Thomas, J., Sosinski, L., Neal, B. And Hammond, L (2013). An evaluation of 2,4-dichlorophenoxyacetic acid in the Amphibian Metamorphosis Assay and the Fish Short-Term Reproduction Assay. Ecotoxicol. and Environ. Saf. 90:143-150.

Farah, M.A., Ateeq, B., Ali, M.N., Sabir, R. And Ahmad, W. (2004). Studies on concentration and toxicity stress of some xenobiotics on aquatic organism. Chemosphere 55:257-265.

Ferrando, M.D., Sancho, E. And Moliner, E.A. (1991). Comparative acute toxicities of selected pesticides to Anguilla anguilla. Environ. Sci. Heath B 26:491-498.

Kubrak, O.I., Atamaniuk, T.M., Husak, V.V. And Lushchak, V.I . (2013). Transient effects of 2,4-dichlorophenoxyacetic acid (2,4-D) exposure on some metabolic and free radical processes in goldfish white muscle. Food Chem. Toxicol. 59:356-361

Matviishyn, T.M., Kubrak, O.I., Husak, V.V., Storey, K.B. And Lushchak, V.I. (2014). Tissue-specific induction of oxidative stress in goldfish by 2,4-dichlorophenoxyacetic acid: Mild in brain and moderate in liver and kidney. Environ. Toxicol. Pharm. 37:861-869

Misra, V., Lal, H., Chawla, G. And, Viswanathan, P.N. (1985). Pathomorphological changes in gills of fish fingerlings (Cirrhina mrigala) by linear alky benzene sulfonate. Ecotoxicol. Environ. Saf. 10:302-308.

Muhammad, S., Shah, T.M. And Khan, S. (2011). Health risk assessment of heavy metals and their sources apportionment in water of Kohistan region, northern Pakistan. Microchem. J. 98:334-343

Okogwu, O.I. and Ugwumba A.O. (2012). Response of phytoplankton functional groups to fluctuating water level in two shallow floodplain lakes in Cross River, Nigeria. Inland Waters 2: 37-46

Okogwu, O.I., Xie P., Zhao, Y. And Fan, H., (2014). Organ-dependent response in antioxidants, myoglobin and neuroglobin in goldfish (Carassius auratus) exposed to MC-RR under varying oxygen level. Chemosphere 112:427-434.

Sarikaya, R. And Yılmaz, M.(2003). Investigation of acute toxicity and the effect of 2,4-D (2,4-dichlorophenoxyacetic acid) herbicide on the behavior of the common carp (Cyprinus carpio L., 1758; Pisces, Cyprinidae). Chemosphere 52:195-201.

Stürtz, N., Ricardo, P.D., Jahn, G.A., Duffard, R., María, A. And de Duffarda, E. (2008). Effect of 2,4-dichlorophenoxyacetic acid on rat maternal behavior. Toxicology 247: 73-79.

Tayeb, W., Nakbi, A., Trabelsi, M., Attia, N., Miled, A. And Hammami M.(2010). Hepatotoxicity induced by sub-acute exposure of rats to 2,4-Dichlorophenoxyacetic acid based herbicide "Désormone lourd" J . Hazard. Mater. 180:225-233.

Tuschl, H, And Schwab, C. (2003). Cytotoxic effects of the herbicide 2,4dichlorophenoxyacetic acid in HepG2 cells. Food Chem. Toxicol. 41:385-393. 
United States Environmental Protection Agency (USEPA), (2005). Reregistration Eligibility Decision for 2,4-D. EPA 738-R-05002. J une 2005.

Uyanıkgil, Y., Yalçınkay, M., Ateş U., Bakaa, M. And Karakişi, H. (2009). Effects of 2,4dichlorophenoxyacetic acid formulation on medulla spinalis of Poecilia reticulata: A histopathological study. Chemosphere 76:1386-1391.

Van Ravenzwaay, B., Hardwick, T., Needham, D.D., Pethen, S. And Lappin G.J. (2003). Comparative metabolism of 2,4dichlorophenoxyacetic acid (2,4-D) in rat and dog. xenobiotica 33:805-821.

Vardia, H.K., Durve, V.S. (1981). The toxicity of 2, 4-D to Cyprinus carpio var. communis in relation to the seasonal variation in the temperature. Hydrobiologia 77:155-159.
Velisek, J., Wlasow, T., Gomulka, P., Svobodova, Z., Dobsikova, R., Novotny, L., Dudzik, M. (2006). Effects of cypermethrin on rainbow trout (Oncorhynchus mykiss). Veterinarni Medicina, 51:469-476.

Wilson, R.D., Armbruster, J.A. (2007). The Dispersion and Dissipation of 2,4-D Concentrations When Used for Typical Aquatic Applications. Available at: /http://www.24d.org/scientificstudies/Environ mental.aspxS.

Zander, R., Lang, W., Wolf, H.W. (1984). Alkaline haematin D-575, a new tool for the determination of haemoglobin as an alternative to the cyanhaemiglobin method. I. description of the method. Clinica Chimica Acta 136: 83-93. 